\title{
Discussion on Preference of Secondary Series of Primary Well Pattern at North Block 1 of Labei
}

\author{
Jin xin \\ No.6 Oil Production Company, Daqing Oil Field
}

Keywords: Class II reservoir; tertiary recovery; secondary series

Abstract: To realize the efficient exploitation of tertiary recovery for the class II reservoir and guarantee the stable replacement of the output, by comparing the thickness and reserve of each series for the class II reservoir at north block 1 of Labei, the article gives preference to S II 13 S III 3 as the secondary series of the primary well pattern, meanwhile preliminarily decides the development time of secondary series, which has guiding significance on developing the secondary series at other blocks.

\section{Introduction}

From the comparison between the thickness and plan design of the actual drilling for the new well, the average sandstone thickness in the actual drilling of class II reservoir for single well is $56.9 \mathrm{~m}$, and the effective thickness is $42.1 \mathrm{~m}$, which is the same with the plan design, however, the average permeability is $0.489 \mu \mathrm{m} 2$, almost twice of the plan design. From the view of water flooding at the new well, the water flooded thickness proportion at the target stratum is $92.2 \%$, which shows the target layer has been better used.

Table1 The comparison of each layer system between actual drilling and the design

\begin{tabular}{|c|c|c|c|c|c|c|}
\hline \multirow[b]{2}{*}{ Series } & \multicolumn{3}{|c|}{ The design } & \multicolumn{3}{|c|}{ Actual drilling } \\
\hline & $\begin{array}{c}\text { Sandstone } \\
\text { thickness (m) }\end{array}$ & $\begin{array}{c}\text { Effective } \\
\text { thickness }(\mathrm{m})\end{array}$ & $\begin{array}{c}\text { Average } \\
\text { permeability } \\
\left(\mu \mathrm{m}^{2}\right)\end{array}$ & $\begin{array}{c}\text { Sandstone } \\
\text { thickness (m) }\end{array}$ & $\begin{array}{c}\text { Effective } \\
\text { thickness }(\mathrm{m})\end{array}$ & $\begin{array}{c}\text { Average } \\
\text { permeability } \\
\left(\mu \mathrm{m}^{2}\right) \\
\end{array}$ \\
\hline $\mathrm{S} I \mathrm{I} 1 \sim 3$ & 7.5 & 6.1 & 0.293 & 6.8 & 5.4 & 0.462 \\
\hline $\mathrm{S}$ II $4 \sim 12$ & 10.0 & 7.1 & 0.237 & 10.4 & 7.3 & 0.454 \\
\hline $\mathrm{S}$ II $13 \sim \mathrm{SIIII} 3$ & 10.5 & 7.2 & 0.262 & 10.6 & 7.7 & 0.444 \\
\hline SIII $4 \sim 10$ & 12.7 & 8.3 & 0.261 & 11.8 & 9.2 & 0.579 \\
\hline P I $4 \sim$ P II 5+6 & 9.2 & 7.3 & 0.222 & 8.7 & 6.2 & 0.508 \\
\hline P II 7-9 G I $4+5$ & 8.6 & 7.2 & 0.166 & 8.7 & 6.3 & 0.465 \\
\hline Total（Average） & 58.5 & 43.1 & 0.240 & 56.9 & 42.1 & 0.489 \\
\hline
\end{tabular}

Table2 The flooding condition of the first layer system

\begin{tabular}{|c|c|c|c|c|c|c|c|c|}
\hline \multirow{2}{*}{ layer } & \multicolumn{2}{|c|}{ High flooded } & \multicolumn{2}{c|}{ Water flooded } & \multicolumn{2}{c|}{ Low flooded } & \multicolumn{2}{c|}{ Not flooded } \\
\cline { 2 - 9 } & $\begin{array}{c}\text { Thickness } \\
(\mathrm{m})\end{array}$ & $\begin{array}{c}\text { Proportion } \\
(\%)\end{array}$ & $\begin{array}{c}\text { Thickness } \\
(\mathrm{m})\end{array}$ & $\begin{array}{c}\text { Proportion } \\
(\%)\end{array}$ & $\begin{array}{c}\text { Thickness } \\
(\mathrm{m})\end{array}$ & $\begin{array}{c}\text { Proportion } \\
(\%)\end{array}$ & $\begin{array}{c}\text { Thickness } \\
(\mathrm{m})\end{array}$ & $\begin{array}{c}\text { Proportion } \\
(\%)\end{array}$ \\
\hline SIII4+5 & 0.5 & 16.4 & 1.2 & 37.6 & 1.0 & 31.2 & 0.3 & 9.6 \\
\hline SIII6+7 & 0.6 & 23.2 & 1.0 & 37.3 & 0.6 & 24.6 & 0.1 & 5.4 \\
\hline SIII8 & 0.3 & 24.2 & 0.5 & 37.8 & 0.3 & 24.6 & 0.1 & 8.5 \\
\hline SIII9 & 0.3 & 28.4 & 0.4 & 40.9 & 0.2 & 19.3 & 0.1 & 7.0 \\
\hline SIII10 & 0.3 & 30.7 & 0.4 & 35.8 & 0.2 & 19.8 & 0.1 & 7.9 \\
\hline SIII4-10 & 2.1 & 22.4 & 3.5 & 37.6 & 2.4 & 25.8 & 0.7 & 7.8 \\
\hline
\end{tabular}

\section{Preference discussion about the secondary series}

Discussion about the thickness for secondary series. In regard of the thickness of each series, that of the primary series is the top one. The average thickness of developed sandstone in a single well is $11.8 \mathrm{~m}$, and the effective thickness is $9.2 \mathrm{~m}$. The thickness of series SII4 12 and SII13 SIII3 is relatively bigger; the average developed-sandstone thickness in a single well is $10.5 \mathrm{~m}$, and the 
effective thickness is $7.5 \mathrm{~m}$, approaching that of the first series.

Discussion about the reserves for secondary series. From the reserve of each series combination, the geological reserves of the primary series are $1295.0 \times 104 \mathrm{t}$. That of SII4 12 and SII13 S III3 is relatively close to that of the primary series, which is favorable for the output linkup.

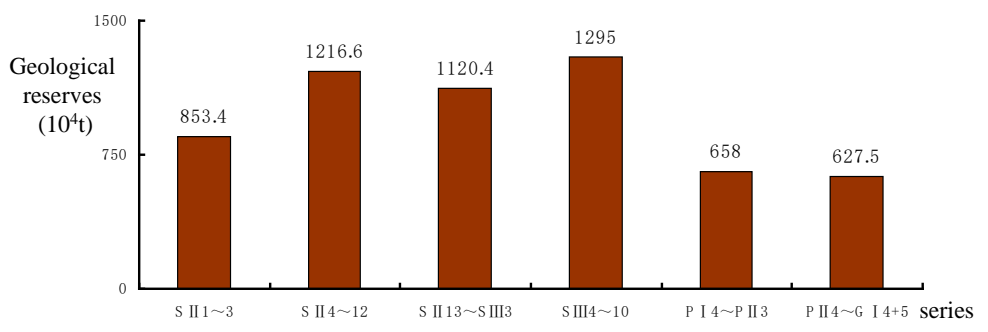

Figure1 Geological reserves of each layer

Discussion about the development effect for secondary series. Seen from the prediction result, recovery ratio can be increased above $13 \%$ at the polymer flooding stage of upward series, but that of the polymer flooding stage of downward series is relatively low. From the initial output after establishment, each series is basically of the same, however, the cumulative oil production of each has bigger difference, and that of SII4 12 and SII13 S III3 is relatively higher, which is relatively close to that of the primary series.

Table 3 Recovery degree of series of strata and recovery efficiency on numerical simulation prediction

\begin{tabular}{|c|c|c|c|c|c|c|}
\hline Series & $\begin{array}{c}\text { Minimum } \\
\text { water } \\
(\%)\end{array}$ & $\begin{array}{c}\text { Well network } \\
\text { encryption } \\
\text { enhanced oil } \\
\text { recovery } \\
(\%)\end{array}$ & $\begin{array}{c}\text { Polymer flooding } \\
\text { encryption } \\
\text { enhanced oil } \\
\text { recovery } \\
(\%)\end{array}$ & $\begin{array}{c}\text { Phase to } \\
\text { encryption } \\
\text { enhanced oil } \\
\text { recovery } \\
(\%)\end{array}$ & $\begin{array}{c}\text { The early } \\
\text { capacity } \\
\left(10^{4} \mathrm{t}\right)\end{array}$ & $\begin{array}{c}\text { The cumulative } \\
\text { oil production } \\
\left(10^{4} \mathrm{t}\right)\end{array}$ \\
\hline S II 1 3 & 80.9 & 2.3 & 13.4 & 15.7 & 14.9 & 134.0 \\
\hline S II 4 12 & 81.2 & 2.3 & 13.1 & 15.4 & 14.7 & 187.4 \\
\hline S II 13 SIII3 & 81.0 & 2.3 & 13.2 & 15.5 & 14.7 & 173.7 \\
\hline SIII4 10 & 79.5 & 2.3 & 14.2 & 16.5 & 15.3 & 213.7 \\
\hline P I 4 P II 5+6 & 81.5 & 2.3 & 11.3 & 13.6 & 13.2 & 89.5 \\
\hline P II 7-9 G I 4+5 & 82.3 & 2.3 & 10.9 & 13.2 & 13.0 & 82.8 \\
\hline Total (Average $)$ & 81.1 & 2.3 & 12.7 & 15.0 & 14.3 & 881.0 \\
\hline
\end{tabular}

All in all, since the petrophysical property of SII13 S III3 oil reservoir is better, the reserves are evenly distributed, and the output replacement capability is the best, so take SII13 S III3 as the secondary series.

\section{Discussion about the development time for secondary series}

From the prediction result under the condition that different water content of the primary series being shifted to subsequent water flooding, when the water content is less than $95 \%$ and shifted to subsequent water flooding, the output input is higher; when it is more than 95\%, the output-input ratio decreases more after being shifted to subsequent water flooding. Therefore, when the water content of the primary series reaches 94\% 95\%, the economic benefit of secondary series development is the best. 
Table4 Different water cut subsequent water flooding mathematical model prediction results

\begin{tabular}{|c|c|c|c|c|}
\hline \multirow{2}{*}{$\begin{array}{c}\text { Predictive project } \\
\text { Recovery }\end{array}$} & \multicolumn{3}{|c|}{ ratio of output to input } \\
\cline { 3 - 5 } & $\begin{array}{c}\text { degree } \\
(\%)\end{array}$ & $\begin{array}{c}\text { oil price } \\
\text { 2500 yuan/ton }\end{array}$ & $\begin{array}{c}\text { oil price } \\
\text { 3000 yuan/ton }\end{array}$ & $\begin{array}{c}\text { oil price } \\
4000 \text { yuan/ton }\end{array}$ \\
\hline $\begin{array}{c}\text { 91\% of subsequent water } \\
\text { flooding }\end{array}$ & 54.53 & 9.44 & 11.33 & 15.11 \\
\hline 92\% of subsequent water flooding & 54.98 & 8.59 & 10.31 & 13.75 \\
\hline 93\% of subsequent water flooding & 55.36 & 4.27 & 5.13 & 6.84 \\
\hline 94\% of subsequent water flooding & 55.57 & 2.12 & 2.55 & 3.4 \\
\hline 95\% of subsequent water flooding & 55.68 & 1.13 & 1.36 & 1.81 \\
\hline 96\% of subsequent water flooding & 55.72 & 0.33 & 0.40 & 0.54 \\
\hline 97\% of subsequent water flooding & 55.76 & 0.21 & 0.26 & 0.34 \\
\hline 98\% of subsequent water flooding & 55.80 & 0.12 & 0.14 & \\
\hline
\end{tabular}

\section{Conclusion}

(1) The situation for sandstone actual drilling of class II reservoir at north block 1 of Labei is basically the same with that of plan design; therefore, developing the series and giving preference to secondary series according to the original plan design.

(2) According to the development thickness, reserves distribution and the result of numerical simulation research of each series, it is decided to take SII13 S III3 as the secondary series of the primary well pattern.

(3) According to the current experience from the tertiary recovery and development, combined with the result of numerical simulation research, the conclusion is when the water content of the primary series reaching $94 \% \sim 95 \%$, the economic benefit of secondary series development is the best.

\section{Bibliography}

Jinxin (1985), male, born in February 1985. Native place: Haerbin, Heilongjiang Province. Holds a Bachelor's degree in petroleum engineering programs from Southwest Petroleum University in 2007. Mid-level engineer. Work in the development of oil and gas field. Address: No.6 Oil Production Company Of Daqing Oil Field, Heilongjiang Province .Tel: 0459-5841319; Email: jinxin3@petrochina.com.cn.

\section{References}

[1] Xu Jianjun, Xu Yan-chao, Yan, Li-me,et.al. Research on the method of optimal PMU placement. International Journal of Online Engineering,v9, S7, p24-29, 2013

[2] Xu Jian-Jun, Y. Y. Zi., Numerical Modeling for Enhancement of Oil Recovery via Direct Current. International Journal of Applied Mathematics and Statistics，2013，43 (13) : 318-326

[3] Longchao, Zhu Jianjun, Xu; Limei, Yan. Research on congestion elimination method of circuit overload and transmission congestion in the internet of things. Multimedia Tools and Applications, p 1-20, June 27, 2016

[4] Yan Limei, Zhu Yusong, Xu Jianjun,et.al. Transmission Lines Modeling Method Based on Fractional Order Calculus Theory. TRANSACTIONS OF CHINA ELECTROTECHNICAL SOCIETY, 2014 ,Vol.29,No. 9:260-268 (In Chinese)

[5] YAN Li-mei, CUI Jia, XU Jian-jun,et.al. Power system state estimation of quadrature Kalman filter based on PMU/SCADA measurements. Electric Machines and Control. 2014, Vol.18 No.6,: 78-84. (In Chinese)

[6] YAN Limei,XIE Yibing, XU Jianjun, et.al. Improved Forward and Backward Substitution in 
Calculation of Power Distribution Network with Distributed Generation. JOURNAL OF XI'AN JIAOTONG UNIVERSITY,2013, Vol.47, No.6, p117-123. (In Chinese)

[7] Xu J.J., Gai D., Yan L.M. A NEW FAULT IDENTIFICATION AND DIAGNOSIS ON PUMP VALVES OF MEDICAL RECIPROCATING PUMPS. Basic \& Clinical Pharmacology \& Toxicology, 2016,118 (Suppl. 1), 38-38

[8]D. R. Wang, “Theory and Empirical Research on Electric Power Demand Response”, North China Electric Power University, Beijing, (2011).

[9]Q. Zhang, X. F. Wang and M. Fu, "Smart grid under demand response”, Automation of Electric Power Systems, vol. 2009, no. 017, (2009), pp. 49-55.

[10]Z. L. Liao and X. B. Ruan, “Energy Management Control Strategy for Stand-alone Photovoltaic Power System”, Proceedings of the CSEE, vol. 29, no. 21, (2009), pp. 46-52.

[11]X. F. Liu, Q. F. Zhang and S. M. Cui, "Review of electric vehicle V2G technology", Transactions of China Electrotechnical Society, vol. 27, no. 2, (2012), pp. 121-127.

[12]Z. C. Hu, Y. H. Song and Z. W. Xu, "Impacts and utilization of electric vehicles integration into power system”, Proceedings of the CSEE, vol. 32, no. 4, (2012), pp. 1-10, 25.

[13]Qu G, Meng Y, Shen A, et al. Experimental Study of the Feasibility of Air Flooding in an Ultra-Low Permeability Reservoir[J]. Energies, 2016, 10

[14]C. Chen, S. Duan S and T. Cai, "Smart energy management system for optimal microgrid economic operation”, Renewable Power Generation, vol. 5, no. 3, (2011), pp. 258-267. 